\title{
ЩОДО МЕЖІ ДОЦІЛЬНОСТІ ВИКОРИСТАННЯ ПОНЯТТЯ "ТРИГЕРНІ ВЗАЄМОДІЇ" У БІОЛОГІЇ ТА МЕДИЦИНІ. ПЕРШЕ ПОВІДОМЛЕННЯ - ПОСТАНОВКА ПРОБЛЕМИ
}

\author{
О. П. Мінцер, К. М. Ігрунова \\ Національна медична академія післядипломної освіти імені П. Л. Шупика
}

\begin{abstract}
Розглянуті можливості використання тригерних форматів для управління корекцією патологічних станів. Проаналізована адаптаційна модель стресу. Показано можливість використання розкиду результатів для оцінки конгруентності компенсаторних реакцій. Як гіпотеза висловлена теза, що в такому випадку тригерні каскади не спрацьовують, оскільки в організмі недостатньо умов для виконання окремих тригерних реакцій. Про це свідчить й низький коефіцієнт доцільності. Стверджується, що для отримання якісного висновку про валідність патогенетичних механізмів можливо користуватися відносним коефіцієнтом варіації і рекомендаціями по величині коефіцієнта і ступеня коливання досліджуваного критерію: до $10 \%$ - слабке коливання; 10-25 \% - помірне коливання; понад $25 \%$ - високе коливання. Показана можливість використання «золотого перетину» для кількісної оцінки рівня метаболічного стану або життєздатності. Останній виявлявся в культурі МНК як співвідношення спонтанного до індукованого апоптозу і в контролі дорівнював значенню "золотого перетину" - 0,614, починав зменшуватися у кролів вже через два тижні стресу - 0,739, і ще більше вичерпувався через чотири тижні стресу - 0,909.
\end{abstract}

Ключові слова: тригерні взаємодії, тригерні каскади, золотий перетин, апоптоз, апоптозний індекс, імунний статус, стрес, корекція патологічних станів, критерій доцільності.

\section{О ПРЕДЕЛЕ ЦЕЛЕСООБРАЗНОСТИ ИСПОЛЬЗОВАНИЯ ПОНЯТИЯ «ТРИГГЕРНЫЕ ВЗАИМОДЕЙСТВИЯ» В БИОЛОГИИ И МЕДИЦИНЕ. ПЕРВОЕ СООБЩЕНИЕ - ПОСТАНОВКА ПРОБЛЕМЫ}

\begin{abstract}
О. П. Минцер, К. Н. Игрунова
Национальная медицинская академия последипломного образования имени П. Л. Шупика

Рассмотрены возможности использования триггерных форматов для управления коррекцией патологических состояний. Проанализирована адаптационная модель стресса. Показана возможность использования разброса результатов для оценки конгруэнтности компенсаторных реакций. Как гипотеза высказан тезис, что в таком случае триггерные каскады не срабатывают, поскольку в организме недостаточно условий для выполнения отдельных триггерных реакций. Об этом свидетельствует и низкий коэффициент целесообразности. Утверждается, что для получения качественного вывода про валидность патогенетических механизмов можно пользоваться относительным коэффициентом вариации и рекомендациями по величине коэффициента и степени колебания исследуемого критерия: до $10 \%$ - слабое колебание; $10-25 \%$ - умеренное колебание; выше 25 \% - высокое колебание. Показана возможность использования «золотого сечения» для количественной оценки уровня метаболического состояния или жизнеспособности. Последний выявлялся в культуре МНК как соотношения спонтанного к индуцированному апоптозу и в контроле равнялся значению "золотого сечения" - 0,614, начинал уменьшаться у кроликов уже через две недели стресса - 0,739, и еще больше исчерпывался через четыре недели стресса - 0,909.
\end{abstract}

Ключевые слова: триггерные взаимодействия, триггерные каскады, золотое сечение, апоптоз, апоптозный индекс, иммунный статус, стресс, коррекция патологических состояний, критерий целесообразности.

\section{EXPEDIENCY LIMITS OF USING THE "TRIGGER INTERACTION" CONCEPT IN BIOLOGY AND MEDICINE. FIRST MESSAGE - STATEMENT OF THE PROBLEM \\ O. P. Mintser, K. M. Ihrunova}

National Medical Academy of Postgraduate Education by P. L. Shupyk

The possibilities of using trigger formats to manage correction of pathological conditions were considered. The adaptation model of stress was analyzed. It is shown the possibility of using the scatter of results to assess congruence compensatory 
reactions. As suggested hypothesis thesis that in this case trigger cascades do not work because there are not enough conditions in the body to fulfill certain trigger reactions. It is proven by the low efficacy coefficient. The relative variation coefficient is optimal for obtaining qualitative conclusion on the validity of pathogenetic mechanisms. It might be useful to follow the recommendations regarding coefficient value and the degree of fluctuation researched criteria: $10 \%-$ weak fluctuations; 10-25\% - moderate fluctuations; more than $25 \%$ - high waves. It is shown the possibility of using "golden proportion" to quantify the level of metabolic condition or viability, which was detected in the culture of MNCs as a ratio to the spontaneous and induced apoptosis in the control of equal value of "golden proportion" -0.614 . It began to decline in rabbits in two weeks of stressing -0.739 and 0.909 - in 4 weeks of stressing.

Key words: trigger interactions, trigger cascade, golden section, apoptosis, apoptotic index, immune status, stress, correction of pathological conditions, criteria of feasibility.

Вступ. У сучасній біології накопичено безпрецедентно великі обсяги експериментальних даних, зберігання, оброблення й осмислення яких неможливо без залучення сучасних інформаційних технологій та ефективних математичних методів аналізу даних, моделювання біологічних систем і процесів. Методи й інструменти інформатики та математичного моделювання грають вирішальну роль у розвитку сучасних галузей молекулярної та клітинної біології і біофізики, структурної біології, фундаментальної медицини, генної інженерії, фізіології.

Однією з найважливіших особливостей функціонування біологічних систем є можливість перемикатися з одного режиму на інший, так званий тригерний режим. Використання тригерних форматів дає можливість отримати стратегічні висновки підходів при поясненні ключових проблем життя та загибелі організму. В останній час вивчення тригерних механізмів функціонування стало широко застосовуватися в медичних дослідженнях [1-3]. Серед цих проблем особливий інтерес представляють проблеми програмованої клітинної смерті - апоптозу.

Вважається, що причинами апоптозу клітин можуть бути як фізіологічні аспекти (збереження генетично заданої чисельності клітин в кожній тканині, стабілізації кордонів тканини; ліквідації клітин, до яких не надходить сигнал до поділу від сусідніх клітин, наприклад, при відсутності молекул факторів росту; знищення нормальних клітин після $50 \pm 10$ ділень - ліміт Хейфліка - через граничне укорочення теломер на кінцях ДНК. Ще більше причин для виникнення апоптозу є у патологічних умовах - знищення клітини з ушкодженнями ДНК - епімутації в генах властивостей клітини, щоб вона не перетворилася на ракову клітину; знищення клітини з ушкодженнями ДНК - ракова клітина, щоб не дала потомства 3 такими дефектами ДНК, тобто рак, ліквідації клітини 3 нерегульованою стимуляцією проліферації за рахунок підвищеної експресії генів c-тус і с-)ип/ або транскрипційного фактора Е2Б; знищення вірус-інфікованих клітин з ушкодженими
ДНК, ліквідації клітин 3 порушеннями клітинного циклу, клітин з порушеними мембранами, які стали аутоантигенними тощо.

За даними літератури, апоптоз може індукувати різні патологічні стани: гостру реструктуризацію стінки лівого шлуночка міокарда [4], зменшення (гальмування) програмованої смерті клітин при серцевій недостатності здатне запобігти дилатації серця та зменшенню його скоротливої здатності, виникненню раптової смерті [5]. Асоціюються 3 програмованою смертю клітин й фізіологічні процеси росту нирки та їі ремоделювання, різні хвороби нирок та медикаментозна нефротоксичність. Розвиток атеросклерозу пов'язаний з ініціацією апоптозу ендотеліальних клітин судин організму прозапальними цитокінами як наслідок запальної реакції [6].

Сепсис є ще одним клінічним проявом апоптозу, бо у таких хворих розвивається масивна програмована смерть імунних ефекторних клітин та епітеліоцитів гастроінтестинальної зони [7, 8, 9].

Особливо важливо, що індукувати (стимулювати) програмовану смерть клітин можуть багато чинників, серед них і медикаменти. Проапоптичну дію мають статини, доксациклін, бромокриптин, допамін, анестетики, аспірин, фібрати, антималярійні препарати, золендронат, протизапальні препарати та багато інших. Стимулюють апоптоз окислені ліпопротеїни низької щільності (ЛПНЩ), чинники, що впливають на окисно-відновні процеси; температурні стреси; іонізуюче та неіонізуюче випромінювання.

Зрозуміло, що прямий вплив на процеси апоптозу в організмі зміг би кардинально змінити саму організацію лікування, його наслідки. Тому плануючи подібне дослідження ми звернули увагу на характер процесу апоптозу, роль пускових механізмів та тригерну ієрархію послідовних реакцій в досліджуваному явищі. Апоптоз є клітинним проявом каскаду тригерних реакцій регуляції від найвищого рівня - мозкового, потім вегетативного, ендокринного, імунного, медіаторного, рецепторного, вторинних месенджерів, до генетичного рівня. 
Стратегічна мета досліджень - обгрунтувати нові принципи корекції патологічних змін в організмі шляхом періодичної направленої зміни тригерних реакцій (каскаду тригерних реакцій).

Мета роботи - вивчення критеріїв, що відображають проведення тригерних реакцій в організмі людини при патології.

Матеріал та методи досліджень. Вивчено вплив стресу на стан специфічної (імунної) та неспецифічної резистентності, продукцію прозапальних цитокінів, ініціацію спонтанного та індукованого апоптозу мононуклеарних клітин крові в експерименті. Для цього досліджували імунний статус. Вивчали формулу крові, субпопуляції лімфоцитів з моноклональними міченими антитілами до $\mathrm{CD}$, імуноглобуліни, ЦІК, фагоцитоз, активність природних клітин кілерів (ПКК). Також досліджували фізіологічні модулятори апоптозу - перекисні сполуки за хемілюмінесценцією плазми крові та рівень прозапальних цитокінів: ФНП, ІЛ-1. Перерахунок вмісту ФНП в пробах крові, визначений за ІЦ,\% в пг/мл здійснювали за калібровочним графіком, який будували при визначенні індексу цитотоксичності в культурі клітин L-929 стандартного зразка речовини порівняння - рекомбінантного фактора некрозу пухлин рифналіну (СЗРП).

В експерименті дослідні тварини були поділені на групи. Дослідні щури були поділені на декілька груп: I - контрольні тварини; II - тварини, у яких протягом двох, або чотирьох тижнів викликали імобілізаційний стрес і за схемою зондом per os вводили $0,9 \%$ розчин $\mathrm{NaCl}$ в об'ємі 1 мл; III - тварини, яким на тлі іммобілізаційного стресу також зондом per os вводили за аналогічною схемою препарат коректор (ПК) у тому ж самому об'ємі. В окремій серії експериментів визначали зміни в організмі щурів, яких до початку стресування було імунізовано еритроцитами барана. Цих тварин також поділяли на вище зазначені групи, однак додатково виділяли ще ІУ групу, до якої входили щури у яких в якості коректора застосовували тімалін. Аналогічні досліди повторювали у весняно-літній та осінньо-зимовий періоди, а деякі й у різні роки.

Кров від щурів одержували після закінчення стресування дослідних груп при декапітації, яку проводили з дотриманням правил евтаназії.

Дослідні кролі також були поділені на декілька груп: I - контрольні тварини; II - тварини, у яких протягом чотирьох тижнів викликали іммобілізаційний стрес $\mathrm{i}$ за схемою зондом per os вводили $0,9 \%$-ний розчин $\mathrm{NaCl}$; III - тварини, яким на тлі іммобілізаційного стресу також зондом per os вводили за аналогічною схемою ПК у тому ж самому об'ємі. Досліди на кролях проводили у весняно-літній період.

Кров у кролів брали з вуха до початку експерименту та після двох тижнів стресування. Крім того, венозну кров отримували при знекровлюванні тварин після чотирьох тижнів стресування, коли виводили $з$ досліду II та III дослідні групи кролів.

Стрес у тварин спричинювали шляхом утримання їх у спеціальних структурах, що обмежували їх рухову активність, протягом певних часових термінів згідно з планом експерименту: термін знаходження тварин у замкнутому просторі становив 1 год. щодоби. 3 десятої доби стресування тваринам починали вводити ПК, або 0,9 \% розчин №C 1 у контрольній групі. У щурів стресування з введенням зазначених препаратів тривало 5 діб, після чого введення продовжували ще одну добу, але без стресування. На наступний день після цього тварин виводили з досліду.

У кролів цикли поєднання стресування з введенням препаратів повторювали двічі, починаючи з 10-ї та з 23-ї доби після початку експерименту, і тривали вони по 6 діб. На 16-ту добу експерименту, коли у кролів брали кров 3 вуха, стресування не проводили. 3 досліду тварин виводили через день після закінчення стресування.

Щурів забивали після закінчення моделювання стресу. На дослідження брали сироватку і стабілізовану гепарином кров (25 ОД/мл). Гетероантиген еритроцити барана (ЕБ) для імунізації вводили в дозі $1 \times 10^{9}$ клітин на тварину.

Після закінчення експерименту тварин декапітували під ефірним наркозом. Всі маніпуляції з тваринами проводили відповідно до Міжнародних принципів Європейської конвенції про захист хребетних тварин, які використовують для експериментів та інших наукових цілей (Страсбург, 1985).

Об'єктом дослідження апоптозу були мононуклеарні клітини (МНК), виділені з крові експериментальних тварин (щурів та кролів), що зазнали впливу іммобілізаційного стресу. Мононуклеарні клітини одержували шляхом центрифугування на градієнті густини фіколурографін $\left.^{\wedge}=1,077\right)$. МНК в концентрації $5 \times 10^{6} /$ мл культивували в об'ємі 200 мкл в культуральному середовищі впродовж 18 год при $37{ }^{\circ} \mathrm{C}$. Культуральне середовище: КРМІ 1640 з $10 \%$ ембріональною телячою сироваткою, 2 мМ глютаміном та антибіотиками в бактеріостатичній концентрації. Для індукції апоптозу застосовували дексаметазон в кінцевій концентрації $10^{-3}$ мг/мл. Через 18 годин інкубації кількість життєздатних клітин визначали стандарт- 
ним методом із 0,1 \% трипановим синім. Клітини, що вступили на шлях апоптозу, визначали методом флуоресцентної мікроскопії за їх здатністю накопичувати барвник Hoechst 33342, який зв'язується 3 ДНК $[10,11]$. Флуоресценцію ядер лімфоцитів реєстрували за допомогою мікроскопу "Люмам I-3". Для кількісної оцінки вмісту апоптичних клітин застосовували апоптичний індекс (AI), що характеризує кількість клітин з морфологічними ознаками апоптозу і визначається за формулою: $\mathrm{AI}=$ кількість апоптичних клітин / загальна кількість клітин х 100 .

Визначали спонтанний апоптоз МНК - в день взяття крові, та AI після 18-годинної інкубації в контрольних зразках (функціональна активність) та в присутності дексаметазону (функціональний резерв).

Статистичну обробку одержаних результатів проводили з використанням непараметричних критеріїв Вілкоксона - Манна - Уїтні а також параметричного $\mathrm{t}$ - критерію Ст'юдента.

Особливості методичного підходу. Нами широко застосовується три поняття: тригерні реакції, тригерний каскад реакцій, доцільність циклу реакцій. Зокрема, використовували поняття тригерних реакцій, розуміючи під ними можливість та умови вибору одного $з$ двох станів системи, що досліджується

Інтерес до динамічних систем тригерного типу обумовлений, перш за все, специфічною для них наявністю двох станів стійкої рівноваги, завдяки яким система може як завгодно довго перебувати в одному 3 двох станів, стрибкоподібно перемикаючись 3 одного в інший під впливом зовнішньої та внутрішньої дії.

За допомогою тригерних моделей вдалося пояснити ряд найважливіших біологічних та патофізіологічних явищ, пов'язаних з перемиканням, наприклад, при зміні типу метаболізму, при генетично запрограмованих переходах від однієї фази розвитку до іншої (наприклад, у більшості комах - яйце-личинка-лялечка-імаго), в процесі диференціювання тканин, а також в динаміці більшої частини захворювань, зокрема з переважанням або руйнування - апоптозу, або розмноження - проліферації.

Важливим є математичне відображення переходу між двома стійкими рівноважними станами в тригерних системах, пов'язаних зі збуреннями системи. Збурення, як правило, задаються варіюванням відповідних параметрів і початкових умов - вихідних станів. Як відомо, динамічні системи, що моделюються кінцевим числом звичайних диференціальних рівнянь, називають зосередженими, або точковими системами. Вони описуються за допомогою кінце- вомірного фазового простору і характеризуються кінцевим числом ступенів свободи. Одна і та ж система в різних умовах може розглядатися або як зосереджена, або як розподілена. Число ступенів свободи розподіленої системи нескінченне, і потрібне нескінченне число даних для визначення ії стану. В роботі ми розглядали як консервативні (з незмінним у часі запасом енергіi), так і неконсервативні динамічні системи, насамперед, дисипативні системи, тобто такі стійкі стани, що виникають у нерівноважному середовищі за умови дисипації енергії, яка надходить ззовні. Дисипативна система характеризується спонтанною появою складної, часто хаотичної структури. Відмінною особливістю таких систем (насамперед, біологічних) є незбереження обсягу в фазовому просторі, тобто невиконання теореми Ліувілля про обмеження цілих аналітичних функцій.

Важливими також для нас є дані останніх досліджень в галузі «дисипативних структур», які дозволяють робити висновок про те, що процес «самоорганізації», що збільшує стійкість системи у другому законі термодинаміки, відбувається набагато швидше за наявності в системі зовнішніх $\mathrm{i}$ внутрішніх «шумів» - тригерів. Таким чином, шумові ефекти призводять до прискорення процесу «самоорганізації», зниження ентропії, руйнування частин організму.

Як відомо, біологічні динамічні системи, як правило, неавтономні, тобто явно залежать від часу, динаміки навколишнього середовища. При варіюванні початкових умов рівняння системи залишаються незмінними, а траєкторії продовжують прагнути до колишньої точки стійкої рівноваги, поки початкова точка не переходить деякого порогового значення (класичного фундаментального закону золотого перетину), відповідного перетинанню сепаратріси, що розділяє на фазовому портреті два стани рівноваги.

Підкреслимо, що дослідження асимптотик по малому параметру рішень нелінійних диференціальних рівнянь другого порядку поблизу сепаратріси складають важливий напрям сучасної теорії диференціальних рівнянь. Завдання такого типу багато років знаходяться в центрі уваги фахівців в теорії динамічних систем.

Природно, особливої актуальності в дослідженні тригерних систем набуває розвиток якісних методів теорії диференціальних рівнянь, оскільки вони являють собою альтернативний підхід до подолання відомих труднощів, що виникають при численних розрахунках і дають рішення системи лише при фіксованих значеннях параметрів і початкових умов. Якісний 
підхід, в свою чергу, не претендуючи на пошук точного рішення системи, найчастіше виявляється корисним для виділення основних режимів динамічної системи, з'ясування зв'язку між ними та аналізу порогових ефектів, що виникають при досягненні параметрами критичних значень. Особливого значення якісні методи набувають при аналізі складних систем, таких як організми, з великою кількістю різних параметрів, точний розрахунок яких зажадав би великих обчислювальних потужностей, а визначення характеристик тригерного каскаду надає можливість скороченого та перспективного аналізу стану організму.

В роботі широко використовували один з найвідоміших в системних дослідженнях принцип «золотого перетину». Він в останні роки привертає все більше уваги. Показано, що у здорової людини, незважаючи на різні конкретні значення гемодинамічних показників, їх співвідношення знаходяться у гармонічній пропорції близьким до величини $\Phi=1,618$, що, власне кажучи, й отримало характеристики «золотого перетину». Часто-густо використовують зворотну величину $1 / \Phi$, що дорівнює 0,618 .

Зауважимо, що подібне співвідношення існує практично у всіх органах та системах. Тому, на думку великої кількості вчених, золотий перетин відображає фундаментальні загальноприродні закономірності. Новий концептуальний підхід, розроблений у Національній медичній академії післядипломної освіти (НМАПО) імені П. Л. Шупика [12], в основу якого покладено вивчення апоптозу, визначення життєздатності клітин серцево-судинної системи за законом золотого перетину, дозволяє запропонувати доступні методи діагностики та виявлення людей груп ризику.

Застосовували також поняття доцільності як відповідності явища або процесу певному (завершеному) стану, ідеальна модель якого представляється як мета. Доцільність розглядається, з одного боку, як іманентний (внутрішній) взаємозв'язок об'єкта самого по собі, а з іншого - як певні стосунки при взаємодії об'єкта і суб'єкта. Ставлення доцільності виступає в якості принципу дослідження структури i функцій саморегулюючих і еквіфінальних систем (тобто систем, здатних досягати однакового кінцевого результату незалежно від початкових умов). Важливим в плані кількісного визначення доцільності є характеристики зворотного зв'язку кінцевого ефекту, результату процесу на його вихідний пункт. Доцільність дозволяє виявити певну спрямованість процесів, їх обумовленість кінцевими результатами, які постають в якості цілей. Подібний цільовий підхід може зорієнтувати відносно процесів в еквіфінальних системах. Для нашого дослідження вкрай важливим є застосування доцільності для характеристики циклічних та поступальних процесів.

В якості критерію доиільності першого рівня використовували математичне очікування коефіцієнтів варіації різних станів.

Результати та їх обговорення. Результати, отримані в серії експериментів, подано в таблиці 1. Як випливає 3 наведених даних, дексаметазон (гормон стресу) не впливав на кількість живих мононуклеарних клітин (МНК) в культурі 1-ї (інтактні) групи тварин. А в 2-й групі (стрес) інкубація з дексаметазоном зменшувала кількість живих клітин в тесті з трипановим синім. В 1-й групі дексаметазон викликав значну індукцію апоптозу в культурі МНК. В 2-й групі AI в контрольних зразках не відрізнявся від такого в інтактній групі, а ДМ викликав достовірне збільшення AI, в порівнянні з контрольними зразками, але ця індукція була меншою, ніж в інтактній групі. В 3-й групі AI в контрольних зразках був вищим за такий в 1-й та 2-й групах, а ДМ достовірно підвищував його, порівняно з контрольними зразками, до величин, характерних інтактній групі.

Таблиця 1. Вплив 2-тижневого іммобілізаційного стресу на індукцію апоптозу в культурі МНК щурів (2-а серія)

\begin{tabular}{|c|c|c|c|c|}
\hline \multirow{2}{*}{$\begin{array}{c}\text { Група } \\
\text { Умови інкубації }\end{array}$} & \multicolumn{2}{|c|}{$\begin{array}{c}\text { I група (інтактні) } \\
\text { n=14 }\end{array}$} & \multicolumn{2}{|c|}{$\begin{array}{c}\text { II група (стрес) } \\
\text { n=16 }\end{array}$} \\
\hline & \% жив. кл. & AI & \% жив. кл. & $\mathrm{AI}$ \\
\hline Контроль & $89,8 \pm 11,9$ & $6,6 \pm 1,4$ & $80,6 \pm 21,6$ & $6,9 \pm 3,9$ \\
\hline ДМ & $84,9 \pm 10,3$ & $19,0 \pm 2,2 * *$ & $69,0 \pm 23,6$ & $13,4 \pm 5,6^{* *}$ \\
\hline
\end{tabular}

Примітки: $1 .{ }^{* *}-\mathrm{p}<0,05$ порівняно $з$ контролем; 2. ДМ - дексаметазон.

Виходячи з одержаних даних можна зробити висновок, що інкубація культури МНК щурів in vitro протягом 18 годин в присутності дексаметазону в кон- центрації $10^{-3}$ мг/мл вела до загибелі шляхом некрозу 14,5 \% кількості клітин, а шляхом апоптозу 64,6 \% клітин. Двотижневий іммобілізаційний стрес 
призводив до загибелі шляхом некрозу 4 \%, і шляхом апоптозу - 49 \% МНК. Через 14 днів стресу здатність МНК відповідати на індукцію апоптозу дексаметазоном in vitro становила 300 \%. ДМТ на фоні 14-денного стресу зменшував кількість живих клітин за рахунок некрозу на 28,7 \%, порівняно з контролем. Це непрямо може свідчити про потенціювання дії ДМТ на фоні стресу та невиражені зміни вмісту глюкокортикоїдів in vivo при 14-денному стресі. При цьому індекс індукції апоптозу, який у контролі дорівнював значенню золотого перетину, при стресі зменшувався $з$ 0,607 до 0,497, що свідчить про активацію МНК у щурів при даній моделі стресу. Отже, зворотний зв'язок при нетривалій дії тригера апоптозу призводить до компенсаторної активації клітин.
Результати визначення АI в культурі МНК кролів після інкубації протягом 18 годин наведено в таблиці 2. В таблиці представлені дані про вплив 2-тижневого іммобілізаційного стресу на апоптоз мононуклеарних клітин кролів. Одержані результати свідчать про те, що 2-тижневий стрес не впливає на життєздатність 18-годинної культури мононуклеарних клітин кролів. Проведені до початку моделювання стресу дослідження показали, що дексаметазон в концентрації $10^{-3}$ мг/мл викликає індукцію апоптозу в 18-годинній культурі МНК кролів. 2-тижневий стрес викликає зростання АІ в контрольних зразках, порівняно з вихідними показниками, і майже не впливає на відповідь МНК на індукцію дексаметазоном.

Таблиця 2. Вплив 2-тижневого іммобілізаційного стресу на індукцію апоптозу в культурі МНК кролів

\begin{tabular}{|c|c|c|c|c|c|c|}
\hline \multirow[t]{2}{*}{$\begin{array}{c}\text { Група } \\
\text { Умови інкубації }\end{array}$} & \multicolumn{2}{|c|}{$\begin{array}{c}\text { I група } \\
\text { (вихідні дані) } \\
\text { n=18 }\end{array}$} & \multicolumn{2}{|c|}{$\begin{array}{c}\text { II група } \\
\text { (стрес } 2 \text { тижні) } \\
\text { n=18 }\end{array}$} & \multicolumn{2}{|c|}{$\begin{array}{c}\text { II група } \\
\text { (стрес } 4 \text { тижні) } \\
\text { n=18 }\end{array}$} \\
\hline & \% жив. кл. & AI & \% жив. кл. & $\mathrm{AI}$ & \% жив. кл. & AI \\
\hline Контроль & $68,8 \pm 21,0$ & $15,6 \pm 3,6$ & $60,1 \pm 16,7$ & $21,5 \pm 16,3$ & $60,3 \pm 21,9$ & $8,0 \pm 3,0$ \\
\hline ДМ & $59,2 \pm 17,7$ & $25,4 \pm 7,6^{* *}$ & $58,4 \pm 15,5$ & $27,1 \pm 17,4$ & $53,5 \pm 29,1$ & $8,8 \pm 3,5$ \\
\hline
\end{tabular}

Примітки: 1. * - $<<0,05$ порівняно з вихідними даними (інтактні тварини); 2. ** - p<0,05 порівняно з контролем; 3. ДМ - дексаметазон.

Дослідження показали, що апоптозний індекс в культурі МНК тварин, що зазнали дії 4-тижневого стресу, значно нижчий, ніж вихідні показники, а дексаметазон практично не викликає індукції апоптозу. Можна зробити припущення, що активація МНК, яку ми спостерігали при 2-тижневому стресі, в результаті 4-тижневого стресу зникає, і їх активність стає навіть меншою, ніж у інтактних тварин, що є характерною рисою виснаження. Таким чином, при подовженні дії стресу того ж тригерного каскаду, що і при 2-тижневому стресі, зворотний зв'язок стає протилежно іншим, тригерна система переходить в протилежний стан.

У культурі МНК кролів 2-тижневий стрес викликав зростання AI на 37,8 \% і зменшення кількості живих клітин за рахунок некрозу на 5 \%, і менше, ніж у щурів, впливав на відповідь МНК на індукцію апоптозу дексаметазоном - 173,7 \% порівняно з вихідними показниками, що свідчить про видову специфіку апоптозного процесу. Дослідження показали, що апоптозний індекс в культурі МНК тварин, що зазнали дії 4-тижневого стресу, становив 51,3\%, рівень живих клітин - 87,6 \% від вихідних показників відповідно, кількість живих клітин при дії ДМТ на фоні стресу становила 77,8 \%, апоптозний індекс становив 56,4 \%, тобто дексаметазон практично не викликав індукції апоптозу. Таким чином, через 4 тижні стресу дія ДМТ in vitro не була вираженою, що опосередковано вказує на підвищення рівня глюкокортикоїдів in vivo та зниження чутливості до них МНК. Рівень метаболічного стану або життєздатності, який виявлявся в культурі МНК як співвідношення спонтанного до індукованого апоптозу і в контролі дорівнював значенню "золотого перетину" - 0,614, починав зменшуватися у кролів вже через два тижні стресування - 0,739, і ще більше вичерпувався через чотири тижні стресу - 0,909. Таким чином, двотижневий стрес призводив в середньому до підвищення рівня енергозалежного процесу - апоптозу в МНК крові дослідних тварин, що збігалося з підвищенням у них в цей період стресу рівня прозапального цитокіну - фактора некрозу пухлин (ФНП).

Якщо розглядати роль цитокінів в апоптозі, то стрес у щурів веде до зміни направленості продукції цитокінів лімфоцитами крові у відповідь на кардіальний антиген.

Для оцінки розвитку стрес-реакції з боку імунної системи можна застосовувати безпосередньо не лише клітинні феномени, а і продукцію факторів, що регулюють клітинну активність. До таких можна 
віднести цитокін МШ, який взагалі розглядають як компонент стресорної реакції [13]. Підвищену увагу до себе МІБ привертає ще й тим, що використовується для оцінки функціональної активності Т-лімфоцитів і наявності специфічної сенсибілізації клітинного типу [14]. В наших дослідженнях ми досліджували продукцію аналога цього цитокіну - ЫБ - ІЛ-1.

Таким чином, іммобілізаційний стрес призводить до підвищення рівня прозапальних цитокінів ІЛ-1 та ФНП в крові дослідних тварин максимально через два тижні стресування через підвищення чутливості імуноцитів до дії ендотоксину. Через місяць дії стресу чутливість імунокомпетентних клітин до ЛПС падає і рівень ФНП в крові знижується, що свідчить про виснаження продукції цитокінів при тривалому стресі, про зниження чутливості імуноцитів до дії природних стимуляторів при тривалому стресі згідно правила вихідного стану Вільдера-Лейтеса.

Через місяць стресування рівень апоптозу МНК і продукція ФНП мононуклеарами у крові знижувалися, що дає можливість пов'язати активність апоптозного процесу з продукцією прозапального цитокіну - ФНП, зміною тригерного каскаду в залежності від часу дії етіологічного фактора та вихідного стану.

Отже, адаптаційна модель стресу характеризувалася активацією неспецифічної резистентності організму переважно за рахунок підвищення рівня прозапальних цитокінів - ІЛ-1 та ФНП, ініціацією апоптозу імунокомпетентних клітин - МНК, що супроводжувалося зміною їх метаболічного стану та функціонального резерву.

Інтегральні характеристики отриманих даних пов'язані з використанням розкиду результатів. Легко бачити, що у кролів після двотижневого стресу дисперсія істотно вища, ніж в інших випадках. Відносний коефіцієнт варіації складає $(75,8 \pm 8,5)$ \% в контрольній вибірці та $(64,2 \pm 9,1) \%$ в дослідній. Це досить великий розкид, що свідчить про відсутність єдиного ланцюга компенсаторних реакцій. Можна в такому випадку стверджувати, що тригерні каскади не спрацьовують в тому сенсі, що в організмі недостатньо умов для виконання окремих тригерних реакцій. Про це свідчить й коефіцієнт доцільності, що, в даному випадку, дорівнює 0,52.

Для отримання якісного висновку про патогенетичні механізми можна користуватися відносним коефіцієнтом варіації і рекомендаціями щодо величини коефіцієнта і ступеня коливання досліджуваного критерію: до $10 \%$ - слабке коливання; 10-25 \% - помірне коливання; понад 25 \% - високе коливання. В розгля- нутому прикладі маємо випадки дуже високого коливання й низької доцільності.

Тригерні системи зустрічаються в неозорому числі явищ живої та неживої природи. Вибір конкретних об'єктів для нашого дослідження визначався як бажанням з єдиних позицій описати процеси, що відбуваються в далеких один від одного системах біології, фізики та хімії, так і актуальністю дослідження самих об'єктів.

Останнім часом в уявлення клініцистів включаються поняття тригерних реакцій. Одне з них - концепція генераторних систем. Їх роль, зокрема, досить докладно вивчається в епілептології, в генезі деяких больових синдромів, порушень поведінки. На жаль, існуюча термінологія вкрай різна (стійкий патологічний стан, генератор детермінантної системи, ауторитміка нейронів, тригерні пункти та ін.) і створює видимість принципових відмінностей в суті. Насправді ж йдеться про феномени одного й того ж самого процесу. На жаль, визнання наявності тригерних механізмів обмежилося чисто клінічними феноменами без фундаментальних досліджень та кількісних уявлень.

Особливої актуальності в дослідженні тригерних систем набуває розвиток якісних методів теорії диференціальних рівнянь, оскільки вони являють собою альтернативний підхід до подолання відомих труд нощів, що виникають при численних розрахунках. Якісний підхід, в свою чергу, не претендуючи на пошук точного рішення системи, найчастіше виявляється корисним для виділення основних режимів динамічної системи, з'ясування зв'язку між ними та аналізу порогових ефектів, що виникають при досягненні параметрами критичних значень. Розробка нової концепції системного підходу до розвитку патології на різних рівнях, яка може проявлятися або раптовим виникненням смерті без попереднього клінічного прояву при тривалому формуванні критичного рівня структурно-функціонального дефіциту життєво важливого органа через дифузне зникнення клітин органа шляхом апоптозу, або хронічним захворюванням 3 характерним клінічним проявом дає можливість розробки діагностичного алгоритму визначення типу розвитку та ступеня ризику патології за рівнем апоптозу, як діагностичного критерію стану життєздатності клітин та їх функціонального резерву. Знання факторів і механізмів, що лежать в основі цих процесів, важливе для проведення принципово різної стратегії запобігання виникненню та лікування критичних станів (інфарктів, інсультів, раптової серцевої смерті), розвитку онкологічних захворювань. Знання 
цих ланок патогенезу лежить в основі пошуку а також розробки підходів цілеспрямованої ефективної корекції гострої і хронічної патології, розробки патогенетично спрямованої корекції регуляторних факторів на початкових і наступних етапах розвитку хвороби, підбір модуляторів апоптозу та проліферації при порушенні життєздатності клітин.

Визначення типу розвитку патології та цілеспрямованого впливу на неї шляхом корекції тригерних механізмів значно підвищить своєчасне запобігання розвитку критичних станів, ефективність лікування та прогноз захворювання, зменшить побічні ефекти фармпрепаратів і ускладнення. Застосування результатів роботи дасть можливість істотно знизити захворюваність і смертність населення, знизити вартість і якість лікування та необхідність госпіталізації.

Тригерними механізмами неспецифічної імунної системи служать конституціонально експресовані клітинні рецептори або сироваткові білки. Завдання цієї системи полягає в негайній реакції з чужорідними патогенами, які проникають в організм (наприклад, з бактеріями, паразитами або аберантами клітин). Специфічна імунна система грунтується на взаємодії між специфічними рецепторами В- і Тлімфоцитів і молекулами чужорідних антигенів (у тому числі і власних тканин, як, наприклад, при аутоімунних захворюваннях). Важливим наслідком початкової реакції між антигеном і В- або Т-клітинами $\epsilon$ проліферація і диференціювання популяцій реактивних лімфоцитів. Індукована імунна система реагує більш специфічно, причому не відразу, а через кілька днів або тижнів. Сучасне уявлення фундаментальної медицини про роль імунної системи в регуляції

\section{Лтература}

1. Даниленко Л. М. Триггерний механизм противоишемического действия эритропоэтина и резвератрола / Л. М. Даниленко, М. В. Покровский, О. О. Новиков // Научные ведомости Белгородского государственного университета. Серия: Медицина. Фармация. - 2012. - Вып. №2 10-2 (129), T. 18. - C. $138-142$.

2. Шаровская Ю. Ю. Локальное взаимодействие клеток и контроль клеточного роста / Ю. Ю. Шаровская, Л. М. Чайлахян // ДАН. - 1999. - Т. 366, № 1. - С. 128-132.

3. Слепков В. А. Математическое моделирование пороговых эффектов в триггерных динамических системах методами качественной теории дифференциальных уравнений : автореф. дис. на соискание научн. степени канд. ф.-м. наук : спец. 05.13.18 / В. А. Слепков. - Красноярск, 2008. $24 \mathrm{c}$.

4. Куимов А. Д. Инфаркт миокарда: клинические и патофизиологические аспекты / А. Д. Куимов, Г С. Якобсон. Новосибирск : изд-во Новосиб. университета, 1992. - 224 с. організму підвищує значення визначення характеристик тригерного каскаду.

Висновки. 1. Необхідна розробка принципово нового механізму оцінювання стану організму людини на основі співвідношень спонтанного апоптозу, індукованого апоптозу, розкиду даних та коефіцієнта доцільності.

2. В нормі співвідношення функціональної активності (АІсп.) до функціонального резерву (АІінд.), що $\epsilon$ оптимальним, дорівнює значенню золотого перетину. Відхилення від цього значення в сторону збільшення функціональної активності означає незабезпеченість іiі функціональним резервом і подальше виснаження. Відхилення в сторону збільшення функціонального резерву свідчать про порушення стимуляції функції і перевагу синтетичних процесів анаболізму над катаболізмом, що може призвести до онкології.

3. Іммобілізаційний стрес супроводжувався ініціацією апоптозу імунокомпетентних клітин - МНК, що проявляється зміною їх метаболічного стану та функціонального резерву в залежності від напрямку динаміки тригерного каскаду, залежного від часу дії етіологічного фактора.

4. Стан функціонального резерву показує напрямок динаміки тригерного каскаду: при підвищенні до стану стійкості - розмноження, при зниженні до стану стійкості - руйнування.

5. Значення співвідношення функціональної активності до функціонального резерву в оптимумі відповідає значенню золотого перетину, що є пороговим значенням при переключенні напрямків динаміки тригерних реакцій.

5. Барсель В. А. Состояние системы ПОЛ у больных ишемической болезнью сердца / [В. А. Барсель, И. С. Щедрина, В. Д. Вахляев и др.] // Кардиология. - 1998. - № 5. - С. 18. 6. Цейликман О. Б. Соотношение между цитокиновой активностью крови и уровнем монооксигеназной активности в печени при стрессорных воздействиях, сопровождающихся повышенной устойчивостью к гипоксии / [О.Б.Цейликман, В. Э. Цейликман, С. В. Сибиряк и др.] // Цитокины и воспаление. - 2004. - № 3. - С. 25-31.

7. Меерсон Ф. З. Первичное стрессорное повреждение миокарда и аритмическая болезнь сердца / Ф. 3. Меерсон // Кардиология. - 1993. - № 5. - С. 58.

8. Юрженко Н. М. Вплив діетону на жирнокислотний склад фосфоліпідів печінки щурів в умовах антиоксидантної недостатності / Н. М. Юрженко // Журнал АМН України. 1998. - Т. 4, № 4. - С. 685-690.

9. Меерсон Ф. 3. Адаптация, стресс и профилактика // Ф. З. Меерсон. - М. : Наука, 1981. - 160 с. 


\section{МЕДИЧНА ІНФОРМАТИКА}

ТА ІНЖЕНЕРІЯ

10. Фильченков А. А. Апоптоз и рак / Фильченков А. А., Стойка Р. С. - К. : Морион, 1999. - 181 с.

11. Susin S. A. The Central Executioner in Apoptosis: Multiple Connections Between Protease Activation and Mitochondria in Fas/APO-1/CD95 - and Ceramide - induced Apoptosis / [S. A. Susin, N. Zazjami, M.m Castedo et al.] // Journal of Experimental Medicine. - 1997. - У 186. - P. 25-37.

12. Пат. № 65985 А Україна Спосіб оцінки функціонального резерву мононуклеарних клітин крові $з$ використанням принципу " золотого перерізу" / Ігрунова К. М. ; заявник та патентовласник Ігрунова К. М. ; опубл. 15.04.2004, Бюл. № 4.

13. Фрейдлин И. С. Структура, функции и регуляция иммунной системы / в кн.- Иммунодефицитные состояния. Под ред. проф. В. С. Смирнова и проф. И. С. Фрейдлин. СПб. : Фолиант, 2000. - С. 17-89.

14. Bucala R. MIF re-discovered: pituitary hormone and glucocorticoid-induced regulator of cytokine production / R Bucala// Cytokine and Growth Factor. - 1996. - Y 7. - P. 1924. 